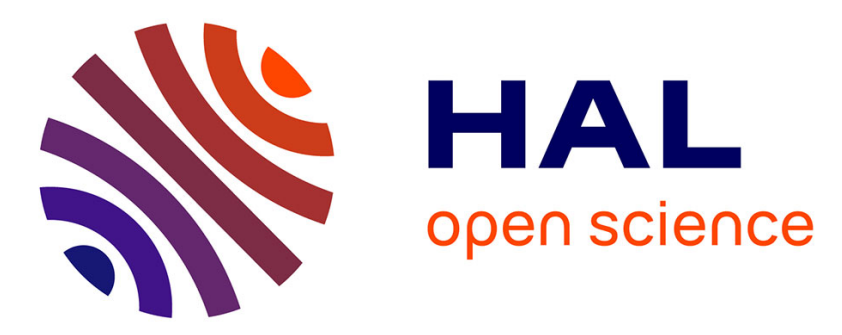

\title{
Ocean wave energy extraction: Up-to-date technologies review and evaluation
}

\author{
Hosna Titah-Benbouzid, Mohamed Benbouzid
}

\section{To cite this version:}

Hosna Titah-Benbouzid, Mohamed Benbouzid. Ocean wave energy extraction: Up-to-date technologies review and evaluation. IEEE PEAC 2014, IEEE, Nov 2014, Shanghai, China. pp.338-342, 10.1109/PEAC.2014.7037878 . hal-01120777

\section{HAL Id: hal-01120777 \\ https://hal.science/hal-01120777}

Submitted on 26 Feb 2015

HAL is a multi-disciplinary open access archive for the deposit and dissemination of scientific research documents, whether they are published or not. The documents may come from teaching and research institutions in France or abroad, or from public or private research centers.
L'archive ouverte pluridisciplinaire HAL, est destinée au dépôt et à la diffusion de documents scientifiques de niveau recherche, publiés ou non, émanant des établissements d'enseignement et de recherche français ou étrangers, des laboratoires publics ou privés. 


\title{
Ocean Wave Energy Extraction: Up-to-Date Technologies Review and Evaluation
}

\author{
Hosna Titah-Benbouzid and Mohamed Benbouzid \\ University of Brest, EA 4325 LBMS \\ Rue de Kergoat, CS 93837, 29238 Brest Cedex 03, France \\ E-mail: Mohamed.Benbouzid@univ-brest.fr
}

\begin{abstract}
The potential of electric power generation from marine renewable energy is enormous. Ocean waves are being recognized as a resource to be exploited for the sustainable generation of electrical power. The high load factors resulting from the fluid properties and the predictable resource characteristics make ocean waves particularly attractive for power generation and advantageous when compared to other renewable energies. Regarding this emerging and promising area of research, this paper presents a complete review of wave energy technologies describing, analyzing and fixing many of the concepts behind wave energy conversion. The proposed review will specifically highlights the main wave energy conversion projects around the world at different levels (demonstration stage, in production, and commercialized projects). In addition, a discussion will highlight challenges that wave energy converters need to overcome to become commercially competitive in the global energy market.
\end{abstract}

Keywords-Marine renewable energy, wave energy converter (WEC), design, challenges.

\section{INTRODUCTION}

One of the very attractive renewable energy sources is the ocean. Indeed, it covers around three quarters of the earth surface and energy can be extracted from the waves, tides, currents, temperature gradients, and salinity gradients. Wave energy, in particular, is spatially more concentrated than both wind and solar energy; it is also more persistent and predictable than wind energy. The global wave power resource has been estimated to be at least $1 \mathrm{TW}$, with a potential annual energy production of about $2000 \mathrm{TWh}$; this is comparable to the energy production from nuclear or hydropower [1-2].

The history of wave power research spans over more than two hundred years. The Frenchman Pierre-Simon Girard is recognized as the first holder of a wave power patent in 1799 [3] (Fig. 1a). Yoshio Masuda may be regarded as the father of modern WEC technology, with studies in Japan since the 1940s. He developed a navigation buoy powered by wave energy, equipped with an air turbine, which was in fact what was later named as a (floating) oscillating water column (Fig. 1b). These buoys were commercialized in Japan since 1965 (and later in USA) [4]. Since then many different other concepts have been conceived. Some of these have come no further than the drawing table, others have made it into small scale models, and a few have also moved on to ocean testing.

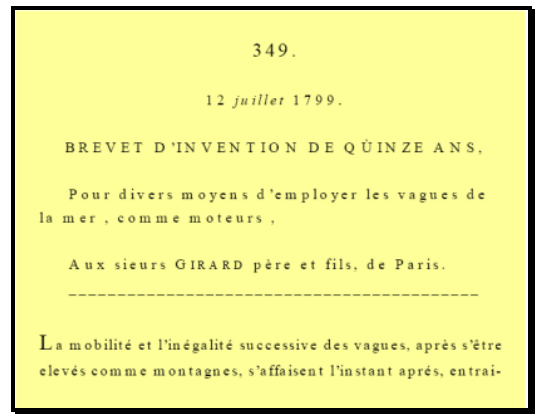

(a) Pierre-Simon Girard WEC patent.

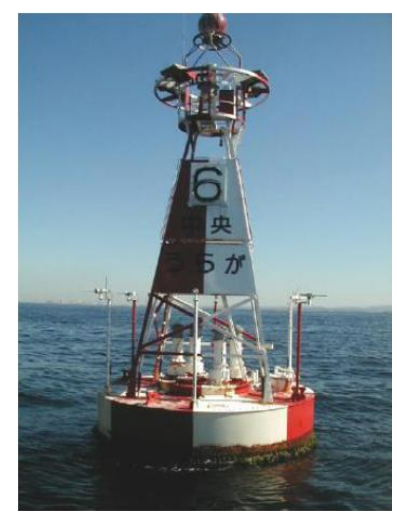

(b) Yoshio Masuda oscillating water column.

Fig. 1. WEC history review.

The technology is still immature and would not commercially exist if it was not subsidized by governments. Therefore, to become a competitive market, it is crucial for the industry to reduce the overall cost of electricity generated from waves. There are many different WEC technologies, and it is not clear which one is superior. WECs developers tend to focus on the prime-mover aspect and use off-the-shelf electrical systems to generate electrical power. These electrical systems usually include a gearbox or a hydraulic system to interface a slow moving prime mover to a conventional high-speed rotary machine. The use of gearboxes or hydraulics introduces potential extra-scheduled and unscheduled maintenance costs. Moreover, the maintenance for offshore devices is much more expensive than onshore equivalents and limited by weather conditions, which results in increased down-time costs. 
The present review aims at giving an update of the most recent trends regarding main wave energy conversion projects around the around at different levels (demonstration stage, in production, and commercialized projects) with respect to overviews already published in the past years [4-7]. In addition, a discussion will highlight challenges that wave energy converters need to overcome to become commercially competitive in the global energy market.

\section{WAVE ENERGY BACKGROUND}

Figure 2 show an atlas of the global power density distribution of the oceans. The north and south temperature zones have the best sites for capturing wave power. The prevailing winds in these zones blow strongest in winter. Increased wave activity is found between the latitudes of $30^{\circ}$ and $60^{\circ}$ on both hemispheres, induced by the prevailing western winds blowing in these regions.

A wave resource is typically described in terms of power per meter of wave front (wave crest length) [5].

$$
P_{w_{-} f}=\frac{1}{8 \pi} \rho g^{2} A^{2} T
$$

where $\rho$ is the water density (approximately $1000 \mathrm{~kg} / \mathrm{m}^{3}$ ), $g$ is the gravity acceleration, $A$ is the wave amplitude, and $T$ the wave period. It can also be described in terms of wave power per meter crest length $\left(P_{w_{-} m c l}\right)$.

$$
P_{w_{-} m c l}=\frac{1}{32 \pi} \rho g^{2} H^{2} T
$$

It should be noted that the wave height $H$ is defined as equal to $2 A$ (Fig. 3).

\section{WAVE ENERGY CONVERTERS}

\section{A. WEC Concepts}

WECs have been developed to extract energy from shoreline out to the deeper waters offshore. These devices are generally categorized by the installation location and the Power Take-Off (PTO) system. Locations are shoreline, near shore and offshore (Fig. 4). In this context, most devices can be characterized as belonging to six types: Attenuator; Point absorber; Oscillating wave surge converter; Oscillating water column; Overtopping device; Submerged pressure differential (Fig. 5).

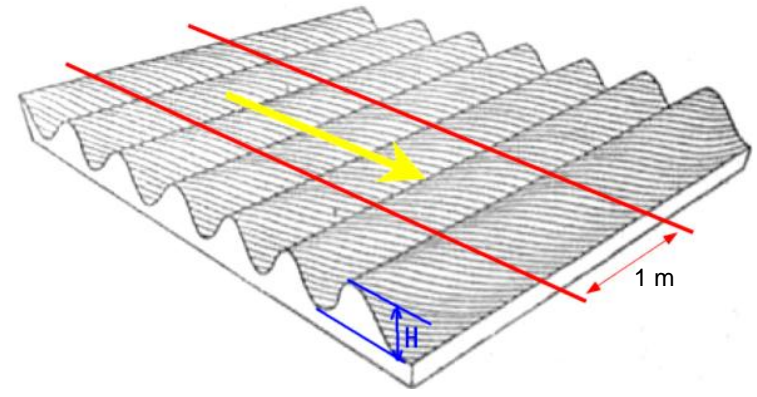

Fig. 3. Wave dimensions.

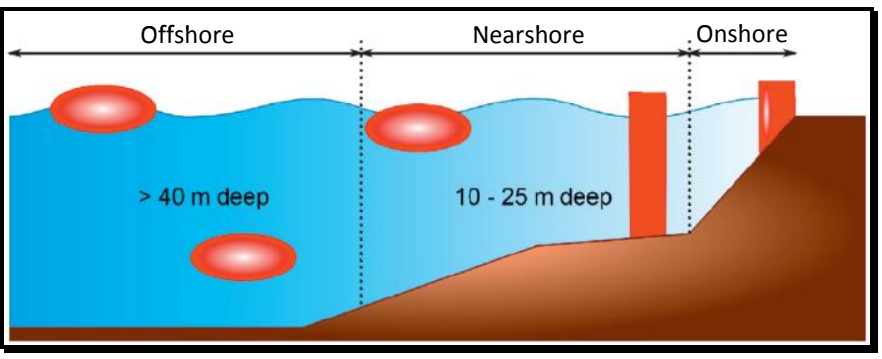

Fig. 4. WECs location.

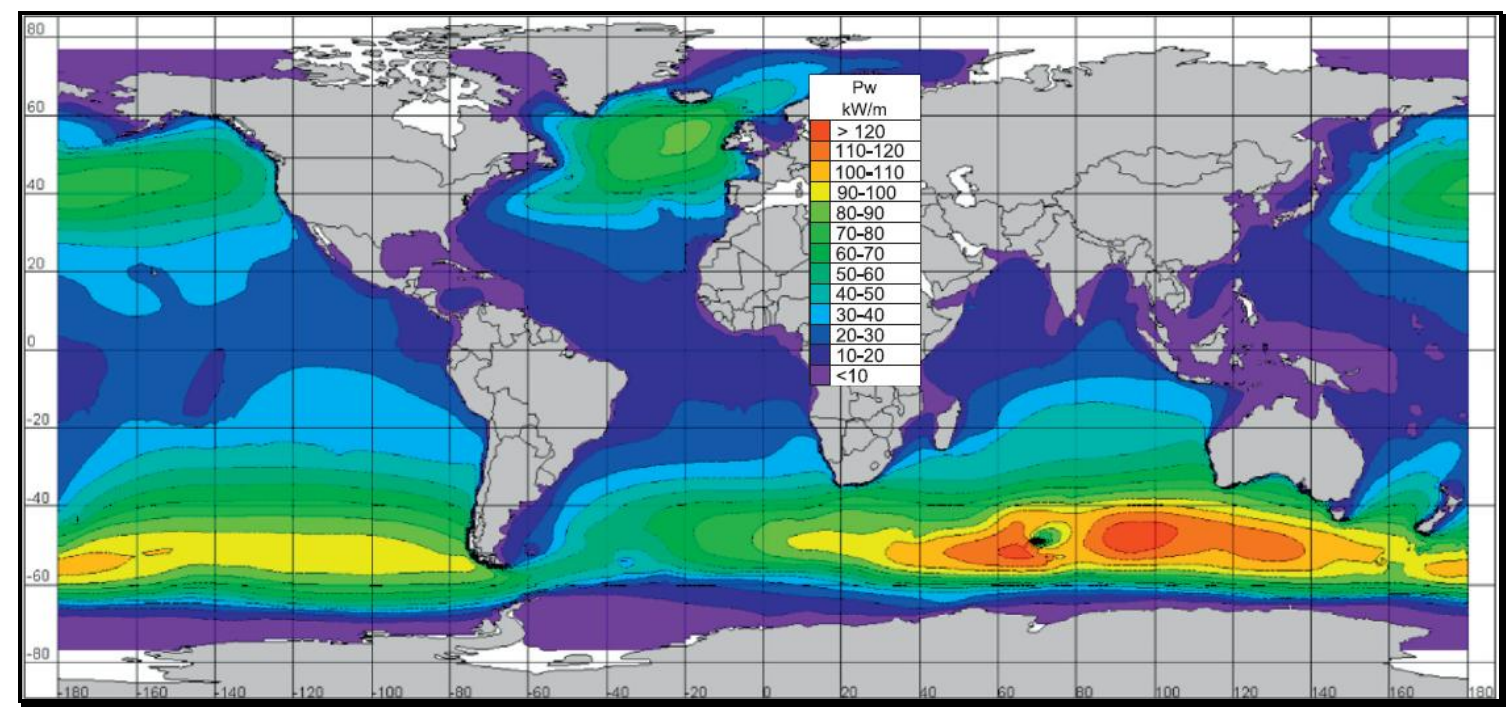

Fig. 2. Global annual mean wave power estimation in $\mathrm{kW} / \mathrm{m}$ spanning 10 years period [6]. 


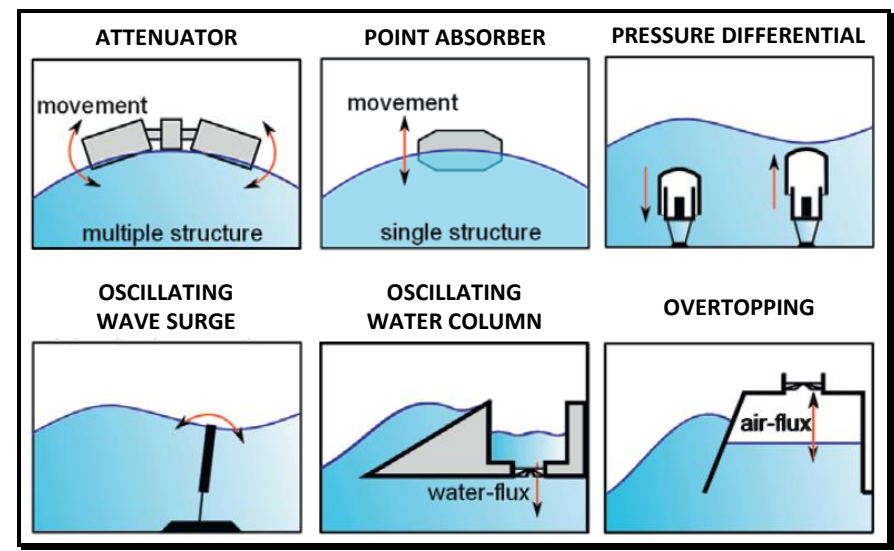

Fig. 5. WECs concepts.

\section{B. WEC Main Projects}

Figure 6 summarizes the main WEC projects in terms of concepts and locations. It should be mentioned that this figure tries to summarize the main and well-known WEC mainly over the demonstration stage. Indeed, there is a large number and variety of WEC that vary in concept and design. In addition to the fact, that there were more than 1000 patents in 2009 [6]. In fact, all of these projects should be considered as in early stages if compared to other renewable technologies (i.e. wind).

\section{WAVE ENERGY EXTRACTION}

Figure 7 summarizes the different conversion stages. In particular this figure shows that there is a variety of ways to extract power from waves: pneumatically, hydraulically, and mechanically (PTO) [8]. This mechanical interface is used to convert the slow rotational speed or reciprocating motion into high speed rotational motion for connection to a conventional rotary electrical generator. In this context, attention will be directed at the mechanism needed to convert wave energy into electricity as most building blocks in the generation system remain nearly the same after being transformed into the electrical form [9].

Linear generators are an option on the testing stage, but they are not yet currently used in most developed WECs [1014]. In particular, different types of linear generators were investigated for the AWS WECs [15-16]. These investigations have led to the conclusion that the transverse flux permanent magnet generator is a good candidate in terms of higher power density and efficiency. The use of permanent magnet synchronous generator is an intermediate option [17-19]. The use of induction generators implies a specific mechanical PTO that induces additional losses affecting the WEC overall efficiency [20-23]. In this context, there are still mechanical engineering challenges. Table 1 summarizes the PTO systems and the electrical generator options for the some of Fig. 6 WEC projects [5].

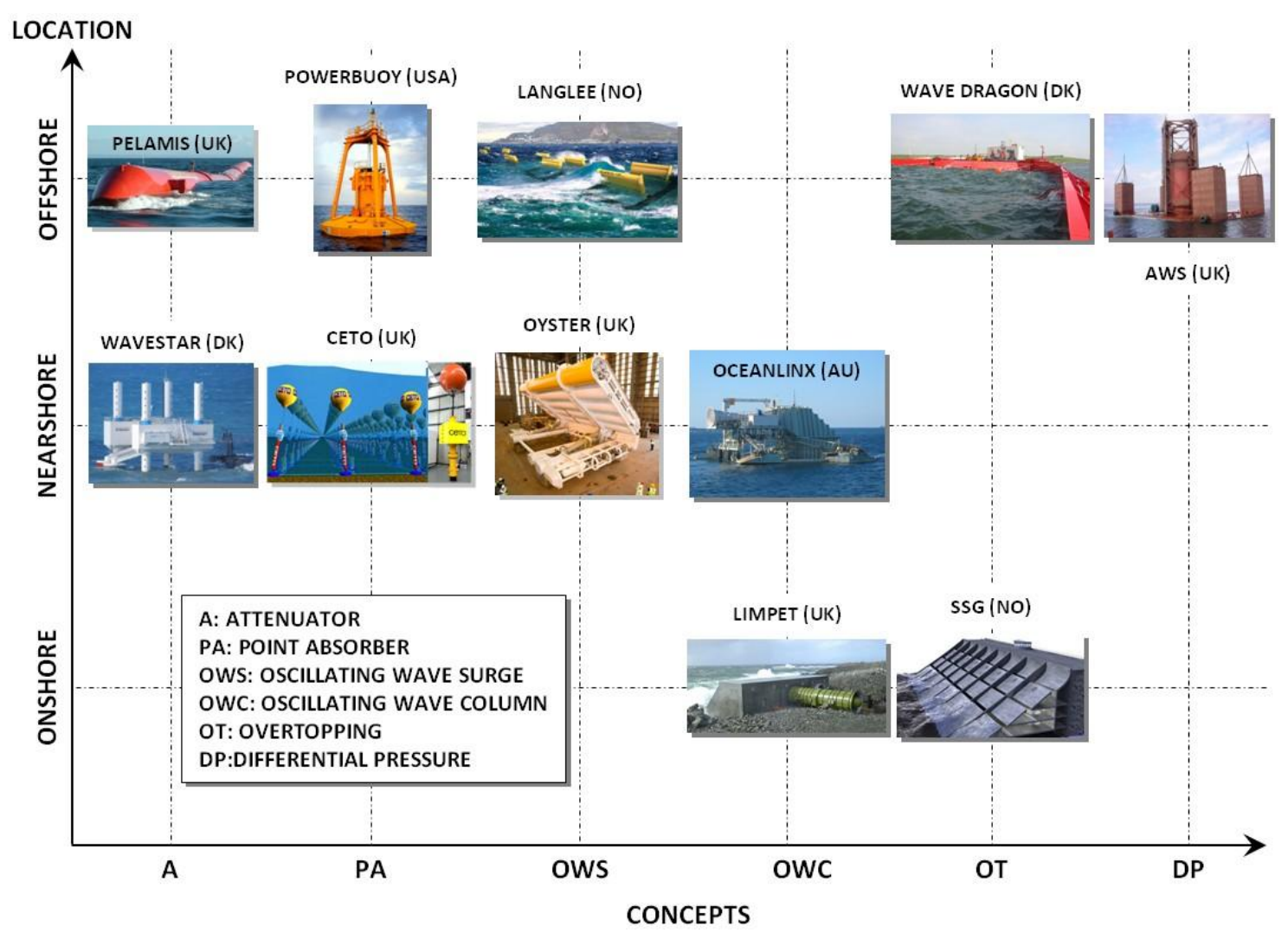

Fig. 6. WECs main projects. 


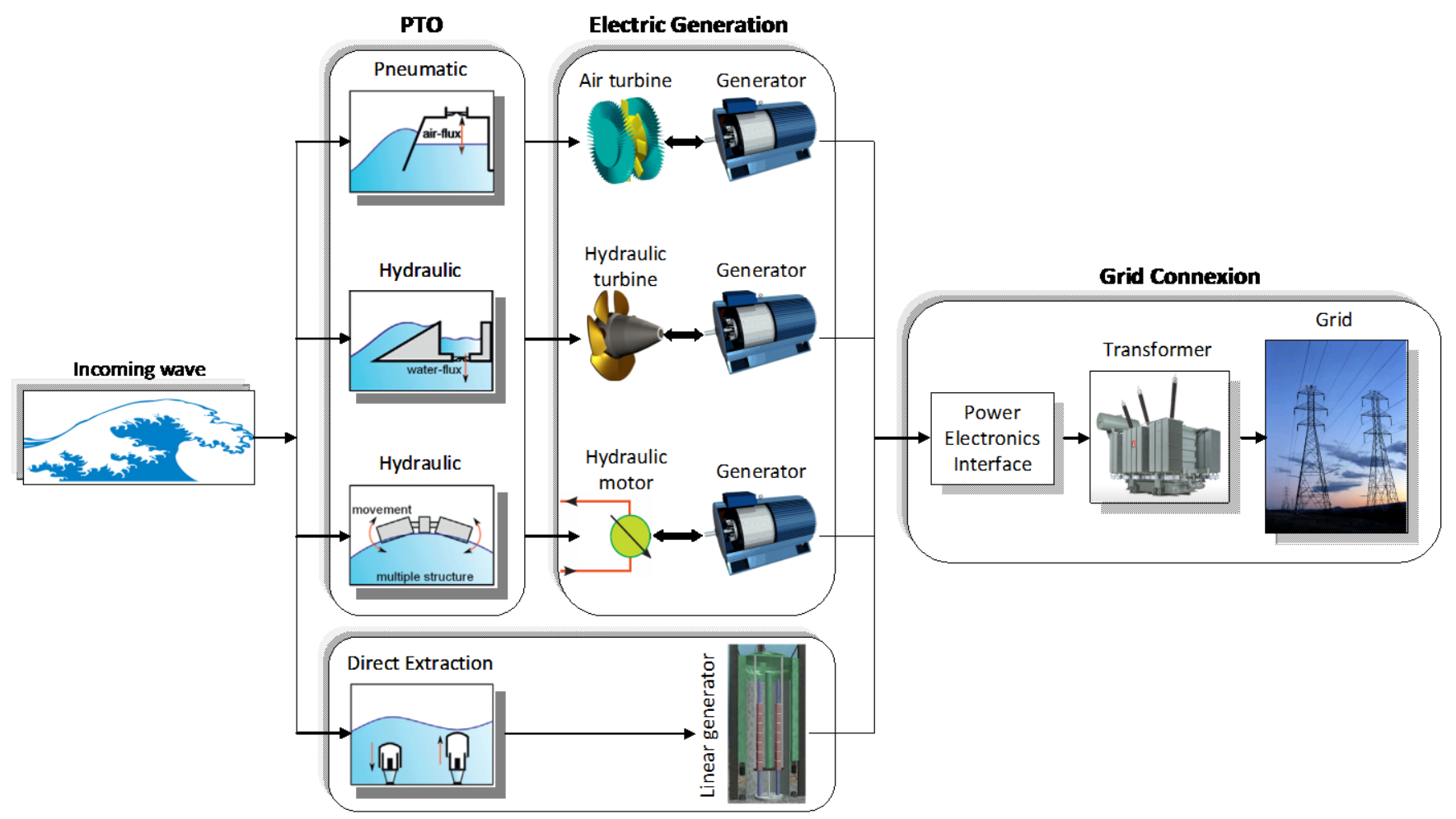

Fig. 7. WEC different type of conversions.

TABle 1. WEC MAIn PROJECTS PTOs AND GENERATORS.

\begin{tabular}{|c|c|c|}
\hline WEC & PTO & Generator \\
\hline PELAMIS & Attenuator/Hydraulics & $\begin{array}{l}\text { Cage induction } \\
\text { generator }\end{array}$ \\
\hline POWERBUOY & Point absorber & $\begin{array}{c}\text { Permanent magnet } \\
\text { synchronous generator }\end{array}$ \\
\hline OYSTER & $\begin{array}{l}\text { Oscillating wave surge } \\
\text { converter }\end{array}$ & $\begin{array}{l}\text { Cage induction } \\
\text { generator }\end{array}$ \\
\hline LIMPET & $\begin{array}{l}\text { Oscillating water column } \\
\text { \& Wells turbine }\end{array}$ & $\begin{array}{l}\text { Cage induction } \\
\text { generator }\end{array}$ \\
\hline OCEANLINX & $\begin{array}{l}\text { Oscillating water colum \& } \\
\text { Denniss-Auld turbine }\end{array}$ & $\begin{array}{l}\text { Cage induction } \\
\text { generator }\end{array}$ \\
\hline PICO [5] & $\begin{array}{l}\text { Oscillating water colum \& } \\
\text { Wells turbine }\end{array}$ & $\begin{array}{l}\text { Doubly-fed induction } \\
\text { generator }\end{array}$ \\
\hline $\begin{array}{c}\text { WAVE } \\
\text { DRAGON }\end{array}$ & $\begin{array}{l}\text { Overtopping \& Kaplan } \\
\text { turbine }\end{array}$ & $\begin{array}{c}\text { Permanent magnet } \\
\text { synchronous generator }\end{array}$ \\
\hline AWS & Direct drive & $\begin{array}{l}\text { Linear permanent } \\
\text { magnet generator }\end{array}$ \\
\hline
\end{tabular}

\section{WAVE ENERGY CONVERTER MOORING}

To use wave energy for electricity generation, WECs must be anchored to the seabed and moored by cables. Similar to other offshore structures moored on the sea floor, a typical WEC mooring system is likely to be composed of three parts: the mooring line, the connectors and the anchor. Chain, wire rope and synthetic fiber rope are the three main mooring line types that are used in offshore structures and could be used for WECs [24]. There are many kinds of connectors used on WECs and other marine structures [24-25]. Anchors are the terminals that transfer the whole system forces to the seabed. The main mooring types, which may be suitable for WECs, can be classed into two kinds as spread mooring and single point mooring. There are several sub-types and it is difficult to define which one is the best without considering the WEC type, location, safety, and cost [26-27].

Mooring design is a critical part of a WEC project. The devices are generally thought to be used in areas of demanding environmental loads due to waves, current and wind. These survivability issues are addressed in existing offshore standards, such as the DNV-OSE301 [28]. In addition, the mooring arrangement can have a direct influence on the WEC operation and on the economic viability of the project [29]. It seems that catenary in spread mooring, catenary anchor leg mooring (CALM) and single anchor leg mooring (SALM) in single point mooring are more popular in practical projects [30].

\section{CHALLENGES FOR COMMERCIAL VIABILITY}

It has been proven that wave energy extraction is very attractive as it is spatially more concentrated than both wind and solar energy; it is also more persistent and predictable than wind energy. On the other hand, the development, from concept to commercial stage, has been found to be a very slow and expensive process [31]. Indeed, it is difficult to follow what was done in the wind turbine industry where at first, 
small machines where developed first, and were subsequently scaled-up to larger sizes and powers for massive deployment. In fact, optimal wave energy absorption involves some kind of resonance. This implies that WECs geometry and size are linked to wavelength. So, if pilot plants are to be tested in the open ocean, they must be large structures [4].

In this specific context, challenges that WECs should to overcome to become commercially competitive leading to massive deployment could be summarized as:

- As for offshore converters, WECs should withstand extreme wave condition leading to difficult and costly maintenance operations.

- As above discussed, mooring design is a critical part. In addition to the demanding environmental loads due to waves, current and wind, the mooring system should also withstand constraints due to the WEC alignment for capture optimization.

- Higher costs of construction, deployment, and maintenance need to be supported with substantial financial support from governments.

\section{CONCLUSION}

As wave energy is having more and more interest and support as a promising renewable resource, although it is still immature compared to other renewable technologies. This paper has proposed an up-to-date review of wave energy technologies with respect to overviews already published in the past years. A discussion has concluded the paper highlighting the challenges that wave energy converters should to overcome to become commercially competitive leading to massive deployment.

\section{REFERENCES}

[1] J. Crus Ed., Ocean Wave Energy: Current Status and Future Perspectives. Springer, Berlin, 2008.

[2] J.G. Vining and A. Muetze, "Economic factors and incentives for ocean wave energy conversion," IEEE Trans. Industry Applications, vol. 45 , $\mathrm{n}^{\circ} 2$, pp. 547-554, March-April 2009.

[3] D. Ross, Power from the Waves. Oxford University Press: 1995

[4] F.A.O. Falcao, "Wave energy utilization: A review of the technologies," Renewable and Sustainable Energy Reviews, vol. 14, n³, pp. 899-918, April 2010.

[5] M.S. Lagoun, A. Benalia and M.E.H. Benbouzid, "Ocean wave converters: State of the art and current status," in Proceedings of the 2010 IEEE ENERGYCON, Manama (Bahraïn), pp. 636-642, December 2010.

[6] I. Lopez, J. Andreu, S. Ceballos, I. Martínez de Alegria and I. Kortabarria, "Review of wave energy technologies and the necessary power-equipment," Renewable and Sustainable Energy Reviews, vol. 27, pp. 413-434, November 2013.

[7] J. Falness, "A review of wave-energy extraction," Marine Structures, vol. 20, n 4, pp. 185-201, October 2007.

[8] K. Rhinefrank et al., "Comparison of direct-drive power takeoff systems for ocean wave energy applications," IEEE Journal of Oceanic Engineering, vol. 37, n ${ }^{\circ}$, pp. 35-44, January 2012.

[9] T.K.A. Brekken, H.M. Hapke, C. Stillinger and J. Prudell, "Machines and drives comparison for low-power renewable energy and oscillating applications," IEEE Trans. Energy Conversion, vol. 25, n4, pp. 1162 1170, December 2010.

[10] L. Cappelli, F. Marignetti, G. Mattiazzo, E. Giorcelli, G. Bracco, S. Carbone, C. Attaianese, "Linear tubular permanent-magnet generators for the inertial sea wave energy converter," IEEE Trans. Industry Applications, vol. 50, n³, pp. 1817-1828, May/June 2014.

[11] C. Bostrom, B. Ekergard, R. Waters, M. Eriksson and M. Leijon, "Linear generator connected to a resonance-rectifier circuit," IEEE Journal of Oceanic Engineering, vol. 38, n², pp. 255-262, April 2013.

[12] T.K.A. Brekken, K. Rhinefrank, A. von Jouanne, A. Schacher, J. Prudell and E. Hammagren, "Scaled development of a novel wave energy converter including numerical analysis and high-resolution tank testing," Proc. IEEE, vol. 101, n4, pp. 866-875, April 2013.

[13] R. Vermaak and M.J. Kamper, "Design aspects of a novel topology aircored permanent magnet linear generator for direct drive wave energy converters," IEEE Trans. Industrial Electronics, vol. 59, n5, pp. 2104 2115, May 2012.

[14] N. Hodgins, O. Keysan, A.S. McDonald and M.A.Mueller, "Design and testing of a linear generator for wave-energy applications," IEEE Trans. Industrial Electronics, vol. 59, n5, pp. 2094-2103, May 2012.

[15] H. Polinder et al., "Conventional and TFPM linear generators for directdrive wave energy conversion," IEEE Trans. Energy Conversion, vol. 20, no. 2, pp. 260-267, June 2005.

[16] M.A. Muller, "Electrical generators for direct drive wave energy converters," IEE Proc. Generation, Transmission \& Distribution, vol. $149, \mathrm{n}^{\circ} 4$, pp. 446-456, July 2002.

[17] M.A. Muller, "Electrical generators for direct drive wave energy converters," IEE Proc. Generation, Transmission \& Distribution, vol. 149, n4, pp. 446-456, July 2002.

[18] S. Olaya, J.M. Bourgeot and M.E.H. Benbouzid, "Modelling and preliminary studies for a self-reacting point absorber WEC," in Proceedings of the 2014 IEEE ICGE, Sfax (Tunisia), pp. 14-19, March 2014.

[19] N. Muller, S. Kouro, J. Glaria and M. Malinowski, "Medium-voltage power converter interface for WaveDragon wave energy conversion system," in Proceedings of the IEEE ECCE, Denver (USA), pp. 352358, September 2013.

[20] M.S. Lagoun, A. Benalia, and M.E.H. Benbouzid, "A predictive power control of doubly fed induction generator for wave energy Converter in irregular waves," in Proceedings of the 2014 IEEE ICGE, Sfax (Tunisia), pp. 26-31, March 2014.

[21] M.S. Lagoun, S. Nadjem, A. Benalia and M.E.H. Benbouzid, "Predictive power control of doubly-fed induction generator for wave energy converters," in Proceedings of the 2012 EFEA (International Symposium on Environment Friendly Energies and Applications), Newcastle upon Tyne (UK), pp. 312-317, June 2012.

[22] M. Alberdi, M. Amundarain, A.J. Garrido and I. Garrido, "Neural control for voltage dips ride-through of oscillating water column-based wave energy converter equipped with doubly-fed induction generator," Renewable Energy, vol. 48, pp. 16-26, 2012.

[23] M. Alberdi, M. Amundarain, A.J. Garrido, I. Garrido and F.J. Maseda, "Fault-ride-through capability of oscillating-water-column-based wavepower-generation plants equipped with doubly fed induction generator and airflow control," IEEE Trans. Industrial Electronics, vol. 58, n5, pp. 1501-1517, May 2011.

[24] Vryhof Anchors: http://www.vryhof.com/ammanual.htm

[25] Bruce Connector: http:// www.bruceanchor.co.uk/

[26] L. Johanning, G.H. Smith and J. Wolfram, "Mooring design approach for wave energy converters," Proc. Inst. Mech. Eng., Part M: Journal of Engineering for the Maritime Environment, vol. 220, n 4 , pp. 159-174, December 2006.

[27] L. Johanning, G.H. Smith and J. Wolfram, "Measurements of static and dynamic mooring line damping and their importance for floating WEC devices," Ocean Engineering, vol. 34,n¹4-15, pp. 1918-1934, 2007.

[28] Det Norske Veritas offshore standard DNV-OS-E301, Position Mooring, October 2010.

[29] F. Cerveira, N. Fonseca and R. Pascoal, "Mooring system influence on the efficiency of wave energy converters," International Journal of Marine Energy, vol. 3-4, pp. 65-81, December 2013.

[30] H. Ming, and G. A. Aggidis, "Developments, expectations of wave energy converters and mooring anchors in the UK," Journal of Ocean University of China, vol. 7, n¹, pp. 10-16, February 2008.

[31] G. Beaudoin, D. Robertson, R. Doherty, D. Corren, B. Staby and L. Meyer, "Technological challenges to commercial-scale application of marine renewables," Oceanography, vol. 23, n² , pp. 32-41, June 2010. 